VI 10 and decreased before a shift to VI 1 . Converse preschedule change effects occurred in the absence of the "warning" stimulus. The directions of rate changes generated by the "warning" stimulus were the same for both component durations, although the trends were slightly more pronounced for 3-min components than for 15-min components.

The prediction that response rates would accelerate before a shift to a VI component of low reinforcement frequency and decrease before a shift to a VI component of high reinforcement frequency in the absence of an exteroceptive "warning" stimulus was not confirmed. The passage of time in VI components did not exert the same discriminative control over behavior as did the programmed preschedule change stimulus.

Whereas the data do suggest the relevance of the presence of an exteroceptive "warning" stimulus in accounting for the discrepancy between the results of the aforementioned investigators, it should not be inferred that temporal cues and exteroceptive stimuli cannot exert comparable discriminative control over behavior in the pigeon (Ferster \& Skinner, 1957). Indeed, had the test conditions been imposed for a longer period, the differences might well have been negligible. In any event, a more definitive statement regarding the role of "warning" stimuli in preschedule change rate shifts must await further investigation involving appreciably more exposure to the same general procedure.

\section{REFERENCES}

FERSTER, C. B., \& SKINNER, B. F. Schedules of reinforcement. $\mathrm{New}$ York: Appleton-Century-Crofts, 1957.

NEVIN, J. A., \& SHETTLEWORTH, S. J. An analysis of contrast effects in multiple schedules. Journal of the Experimental Analysis of Behavior, 1966, 9, 303-315.

PLISKOFF, S. S. Rate-change effects during a pre-schedule-change stimulus. Journal of the Experimental Analysis of Behavior, 1961, 4, 383-386.

PLISKOFF, S. S. Rate-change effects with equal potential reinforcements during the "warning" stimulus. Journal of the Experimental Analysis of Behavior, 1963, 6, 557-562. NOTE

1. Reprints may be obtained from David A. Gibson, Department of Psychology, University of Tennessee at Martin, Martin, Tenn. 38237.

\title{
Conspecific odors as cues for runway behavior in mice
}

\author{
STEPHEN F. DAVIS, King College, \\ Bristol, Tenn. 37620
}

Fourteen mice served as $S$ in a test of the odor hypothesis. All Ss received 104 acquisition trials administered in a double-alternation sequence of reward and nonreward. The results indicated that the mice were able to learn the double-alternation sequence when odor cues were maximized and unable to do so when odor cues were minimized. These results are seen as being comparable to those reported when other species were used as Ss.

Ludvigson \& Sytsma (1967) reported a study in which Ss learned to perform appropriately (fast to reward, slow to non reward) a double-alternation task supposedly on the basis of qualitatively or quantitatively different olfactory cues that were differentially emitted on reward (R) and nonreward $(\mathrm{N})$ trials. Other studies (McHose \& Ludvigson, 1966; Morrison \&
Ludvigson, in press; Ludvigson, 1969; and Davis \& Ludvigson, 1969) have tended to support the odor hypothesis. Also, a recent study by Topping \& Cole (1969), using Mongolian gerbils as Ss, corroborated the odor hypothesis.

The present study was designed to extend the generality of the odor hypothesis by using a different species, the albino mouse, as the $\mathbf{S}$. As far as possible, the procedure reported by Ludvigson \& Sytsma (1967) was employed.

\section{SUBJECTS}

Fourteen male albino mice (FDP/SW strain), purchased from Mouse House, Inc., were used as Ss. The Ss were housed in individual cages with water always available. During the experiment, the Ss were maintained at $85 \%$ ad lib body weight.

\section{APPARATUS}

A $60.96-\mathrm{cm}$ straight runway served as the apparatus. Guillotine doors separated a $15.24-\mathrm{cm}$ white startbox and a $15.24-\mathrm{cm}$ black goalbox from a $30.48-\mathrm{cm}$ black run section. Raising the starting door activated a Standard Electric timer that was stopped by breaking a photoelectric beam located over the goal cup. The apparatus was $50.8 \mathrm{~mm}$ wide and $63.0 \mathrm{~mm}$ tall. Plexiglas lids covered the entire apparatus.

\section{PROCEDURE}

Upon receipt from the supplier, all Ss were placed on ad lib food for 1 week. At the end of this time, deprivation was begun. All Ss were maintained throughout the experiment at $85 \%$ of their mean ad lib weights. When all Ss had reached $85 \%$ of their ad lib weights, pretraining was begun. Pretraining, which consisted of handling and taming, habituation to the reward pellets, and habituation to the unbaited apparatus, lasted for 4 days. At the end of pretraining, the Ss were assigned randomly to two equal groups: $E$ and $C$. Furthermore, each $\mathrm{S}$ was assigned randomly a permanent ordinal position (1-7) within his group. During the experiment, the Ss received all trials in this order, and all Ss in a group received a given trial before the next trial was administered. All the daily trials for a particular group were given before the other group was run. The groups alternated with respect to which was run first daily.

All Ss received $52 \mathrm{R}$ and $52 \mathrm{~N}$ trials at the rate of $8(4 R 4 N)$ trials per day. A reward was one 45-mg Noyes pellet. On N trials, each $\mathrm{S}$ was confined to the goalbox for $20 \mathrm{sec}$. The schedules for the daily administration of trials are presented in Table 1. As can be seen from Table 1, Groups $\mathrm{E}$ and $\mathrm{C}$ differed with respect to the within-trial $R, N$ sequence. Group $E$ had a homogeneous within-trial sequence (odor maximizing conditions), while Group C had a heterogeneous within-trial sequence (odor minimizing conditions). To prevent odor from one trial affecting performance on the next trial, the entire apparatus was swabbed with a damp sponge before the running of $S 1$ in both groups.

\section{RESULTS AND DISCUSSION}

Figure 1 shows the mean speeds (meters per second) for the four trials of the double-alternation sequence. As in previous studies, the double-alternation patterning (fast to $\mathrm{R}$, slow to $\mathrm{N}$ ) was very pronounced for Group E, but virtually nonexistent for Group C. Analysis of variance yielded a significant Reinforcement Conditions ( $R$ vs $N$ ) by Groups interaction $(F=10.63$, df $=1 / 12, p<.01)$. Subsequent Newman-Keuls analysis indicated that the patterning was significant $(p<.01)$ for Group E, but not for Group C.

These results would appear to support the conclusions made by the previous studies (Ludvigson \& Sytsma, 1967; 
Table 1

Schedules for the Daily Administration of $R$ and $N$ Trials. Trials 1 and 8 for Ss 2, 4, and 6 in Group $C$ were excluded from the data.

\begin{tabular}{|c|c|c|c|c|c|c|c|c|c|}
\hline & \multirow[b]{2}{*}{$\mathbf{S}$} & \multicolumn{8}{|c|}{ Trial } \\
\hline & & 1 & 2 & 3 & 4 & 5 & 6 & 7 & 8 \\
\hline \multirow{7}{*}{ Group E } & 1 & R1 & R2 & $\mathrm{N} 1$ & N2 & R1 & $\mathrm{R} 2$ & N1 & N2 \\
\hline & 2 & $\mathbf{R}$ & $\mathbf{R}$ & $\mathbf{N}$ & $\mathbf{N}$ & $\mathbf{R}$ & $\mathbf{R}$ & $\mathbf{N}$ & $\mathrm{N}$ \\
\hline & 3 & $\mathbf{R}$ & $\mathbf{R}$ & $\mathbf{N}$ & $\mathbf{N}$ & $\mathbf{R}$ & $\mathbf{R}$ & $\mathbf{N}$ & $\mathbf{N}$ \\
\hline & 4 & $\mathbf{R}$ & $\mathbf{R}$ & $\mathbf{N}$ & $\mathbf{N}$ & $\mathbf{R}$ & $\mathbf{R}$ & $N$ & $\mathbf{N}$ \\
\hline & 5 & $\mathbf{R}$ & $\mathbf{R}$ & $\mathbf{N}$ & $N$ & $\mathbf{R}$ & $\mathbf{R}$ & $\mathbf{N}$ & $\mathbf{N}$ \\
\hline & 6 & $\mathbf{R}$ & $\mathbf{R}$ & $\mathbf{N}$ & $\mathbf{N}$ & $R$ & $\mathbf{R}$ & $\mathbf{N}$ & $\mathbf{N}$ \\
\hline & 7 & $\mathbf{R}$ & $\mathbf{R}$ & $\mathbf{N}$ & $\mathbf{N}$ & $\mathbf{R}$ & $\mathbf{R}$ & $\mathbf{N}$ & $\mathbf{N}$ \\
\hline \multirow{7}{*}{ Group C } & 1 & R1 & $\mathrm{R} 2$ & N1 & $\mathrm{N} 2$ & R 1 & $\mathrm{R} 2$ & N1 & N2 \\
\hline & 2 & $\mathbf{R}$ & N1 & N2 & R1 & R2 & N1 & N2 & $\mathbf{R}$ \\
\hline & 3 & N1 & N2 & R 1 & $\mathbf{R} 2$ & N1 & N2 & R1 & R2 \\
\hline & 4 & $\mathbf{N}$ & R1 & R2 & N1 & N2 & R 1 & R2 & $\mathbf{N}$ \\
\hline & 5 & R 1 & R2 & N1 & N2 & R 1 & $\mathrm{R} 2$ & N1 & N2 \\
\hline & 6 & $\mathbf{R}$ & N1 & N2 & R1 & $\mathrm{R} 2$ & N1 & $\mathbf{N} 2$ & $\mathbf{R}$ \\
\hline & 7 & N1 & $\mathrm{N} 2$ & R1 & R2 & N1 & $\mathrm{N} 2$ & R 1 & R2 \\
\hline
\end{tabular}

Ludvigson, 1969) about the effects of trial sequence (presumably odor effects) on behavior. Thus, the generality of the odor hypothesis would appear to be extended by showing the influence of strict trial sequence on the behavior of another organism, the albino mouse.

In addition to this major finding, the data resemble the rat data (Ludvigson \& Sytsma, 1967) in several ways. First, for Ss receiving the odor maximizing conditions, the speed of responding on R2 trials generally is faster than on R1 trials. Also, the speed of responding on N1 trials generally is faster than on $\mathrm{N} 2$ trials. Second, the acquisition of the $\mathrm{R} v \mathrm{v}$ discrimination appears to have occurred after approximately the same number of trials in the present study and the one reported by Ludvigson \& Sytsma (1967).
Third, these data are consistent with those presented by Ludvigson (1969) in showing that the nondiscriminating Ss generally show faster speeds than the discriminating Ss.

However, one difference between the rat and mice data is apparent. The rate of approach to asymptotic speed appears to be steeper for the rat Ss (Ludvigson \& Sytsma, 1967) than it is for the mice.

These results, in conjunction with those reported for rat and gerbil Ss, indicate that trial sequence (i.e., odor cues) is potentially a significant variable for a number of species used in runway studies.

\section{-REFERENCES}

DAVIS, S. F., \& LUDVIGSON, H. W. The "depression effect" and the problem of odor control. Psychonomic Science, 1969, 14, 93-94.

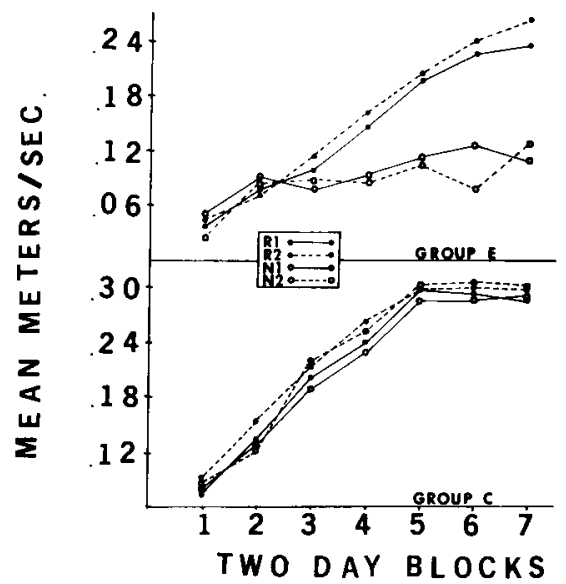

Fig. 1. Mean speeds for $R$ and $\mathbf{N}$ trials. (Note: The first point represents only those eight trials given on Day 1.)

LUDVIGSON, H. W. Runway behavior of the rat as a function of intersubject reward contingencies and constancy of daily reward schedule. Psychonomic Science, 1969, 15, 4143.

LUDVIGSON, H. W., \& SYTSMA, D. The sweet smell of success: Apparent double alternation in the rat. Psychonomic Science, 1967, 9, 283-284.

McHOSE, J. H., \& LUDVIGSON, H. W. Differential conditioning with nondifferential reinforcement. Psychonomic Science, 1966, 6, 485-486.

MORRISON, R. R., \& LUDVIGSON, H. W. Discrimination by rats of conspecific odors of reward and nonreward. Science, in press.

TOPPING, J. S., \& COLE, J. M. A test of the odor hypothesis using Mongolian gerbils and a random trials procedure. Psychonomic Science, 1969, 17, 183-184. 